Archives of Agriculture and Environmental Science

\title{
Response of maize (Zea mays L.) hybrids to different levels of nitrogen
}

\author{
Reena Sharma ${ }^{1^{*}}$ (D) , Parbati Adhikari ${ }^{1}$, Jiban Shrestha ${ }^{2}$ and Binod Prasad Acharya ${ }^{1}$ \\ ${ }^{1}$ National Maize Research Program, NARC, Rampur, Chitwan, NEPAL \\ ${ }^{2}$ Agriculture Botany Division, NARC, Khumaltar, Lalitpur, NEPAL \\ ${ }^{*}$ Corresponding author's E-mail: reenanarc@gmail.com
}

\section{ARTICLE HISTORY}

Received: 21 July 2019

Revised received: 24 August 2019

Accepted: 02 September 2019

\section{Keywords}

Grain yield

Maize hybrids

Nitrogen fertilizer

Spring season

\begin{abstract}
Nitrogen is one of the key factors for higher grain production of hybrid maize (Zea mays L.). The use of improved varieties and optimal use of nitrogen $(N)$ fertilizer is important for exploiting yield potential of maize. This work was carried out to evaluate the effects of $\mathrm{N}$ rates on grain yield and yield attributing traits of hybrid maize. Two hybrids (RML-86/RML-96 and RML-95/RML-96) and five levels of nitrogen (120, 150, 180, 210 and $240 \mathrm{~kg} \mathrm{~N} / \mathrm{ha}$ ) were evaluated at research field of National Maize Research Program (NMRP), Rampur, Chitwan, Nepal in spring season of 2017 and 2018. The experiments were conducted in two factorial randomized complete block design (RCBD) with three replications under rainfed condition. The pooled analysis (2017 and 2018) showed that the highest grain yield 10.5 and $10.5 \mathrm{t} /$ ha were given by hybrids RML86/RML96 and RML95/RML96, respectively with the use of $150 \mathrm{~kg} \mathrm{~N} /$ ha in 2017. The hybrids RML-86/RML-96 and RML-95/RML-96 produced the highest grain yield 7.49 and $7.68 \mathrm{t} / \mathrm{ha}$, respectively with the use of $150 \mathrm{~kg} \mathrm{~N} / \mathrm{ha}$ in 2018 . The mean grain yield (2017 and 2018) showed that both maize hybrids produced the highest grain yield $10.5 \mathrm{t} /$ ha in 2017 and 7.58 t/ha year in 2018 with the application of $150 \mathrm{~kg} \mathrm{~N} / \mathrm{ha}$. The application of nitrogen fertilizer on grain yield was found significant $(P<0.05)$ in both years. Therefore, the application of $150 \mathrm{~kg} \mathrm{~N} /$ ha has significantly increased grain yield of maize, Therefore, this dose of nitrogen can be recommended for higher maize production in Chitwan, Nepal in spring season under rainfed condition.
\end{abstract}

(C)2019 Agriculture and Environmental Science Academy

Citation of this article: Sharma, R., Adhikari, P., Shrestha, J. and Acharya, B.P. (2019). Response of maize (Zea mays L.) hybrids to different levels of nitrogen. Archives of Agriculture and Environmental Science, 4(3): 295-299, https://dx.doi.org/10.26832/24566632.2019.040306

\section{INTRODUCTION}

Maize (Zea mays L.) is second most important crop of Nepal after rice. It is grown in 0.9 million ha with the production of 2.3 million ton ( $t$ ) and Productivity of $2.56 \mathrm{t} /$ ha (MOALD, 2018). Ecologically, it is commonly cultivated in terai, mid hills and high hills as well. Maize is mostly grown under rain fed conditions and mostly on marginal land with very little use of commercial fertilizers. Spring maize can be incorporated in a most common rice wheat cropping system in lowland conditions. It is generally harvested for green cob and get economic return and to utilize time between wheat harvesting and rice planting. The productivity of maize is largely dependent on its nutrient management. Among the fertilizers, nitrogen $(N)$ is very important because this element is responsible on major activities for growth and development of maize crop (Jat et al., 2013). The use of $\mathrm{N}$-fertilizers along with other nutrients has been suggested to enhance the crop productivity (Marschner, 1995). The response of maize plant to application of $\mathrm{N}$ fertilizers varies from variety to variety, location to location and also depends on the availability of the nutrients (Onasanya et al., 2009). Previous findings indicated that the increase in maize grain yield after nitrogen fertilization is largely due to an increase in the number of ears per plant, increase in total dry matter distributed to the grain and increase in average ear weighing (Nxumalo et al., 1993). The nitrogen affects various physiological and biochemical processes in plant cells and, ultimately, affects growth and development (Brady, 1990). A higher level of Nitrogen (180 kg N/ha) improved seed 
yield to $2.85 \mathrm{t} / \mathrm{ha}$ of inbred (NML-1) maize (Adhikary and Adhikary, 2013). Nitrogen response by maize differs due to growth stages, environment and genotype of maize. Hybrid and improved maize varieties are more nitrogen-responsive than local varieties of maize (Shrestha et al., 2018a). Grain yield, days to flowering, plant height, ear height, kernel rows per ear, no. of kernels per row, ear length and thousand grain weight significantly affected due to growing seasons and split applications of nitrogen (Adhikari et al., 2016). The application of nitrogen significantly increased the physiological growth indices of maize hybrids (Abubakar et al., 2019). The information on optimum rate of nitrogen on hybrid maize was not sufficient in Nepal. Therefore, this study was carried out to determine the effect of various levels of nitrogen application on grain yield and yield attributing traits in hybrid maize during spring season.

\section{MATERIALS AND METHODS}

\section{Experimental site}

The experiments were carried out at the research field of National Maize Research Program (NMRP) Rampur, Chitwan in the spring season from March to June of the years of 2017 and 2018. Geographically the experimental site is located at $27^{\circ} 37^{\prime}$ North Latitude and $84^{\circ} 29^{\prime}$ East longitude at an altitude of 225 meter above sea level (Kandel et al., 2017). This site contains only sandy loam soil with acidic reaction. This research location is characteristics of subtropical climate. The plant materials were collected from NMRP, Rampur, Chitwan, Nepal. Maize can be grown throughout the year in Chitwan district and can also be grown in other similar environments (Govind et al., 2015). The weather parameters recorded during the field experiments was given in Table 1.

\section{Plant materials}

Two pipeline hybrids RML-86/RML-96 and RML-95/RML-96 were used in this study. The plant materials were derived from National Maize Research Program (NMRP) Rampur, Chitwan, Nepal.

\section{Experimental detail and field trial management}

The experiments were conducted in two factorial randomized complete block design (RCBD) with three replications. Two hybrids (RML-86/RML-96 and RML-95/RML-96) and five levels of nitrogen (120,150,180, 210 and $240 \mathrm{~kg} \mathrm{~N} / \mathrm{ha}$ ) were used in these experiments. The hybrids were planted in the spacing of 60 $\mathrm{cm} \times 25 \mathrm{~cm}$. The plot size was $3.6 \mathrm{~cm} \times 5 \mathrm{~cm}$ used for the cultivation. The irrigation system was rainfed. Farm Yard Manure (FYM) was applied as $10 \mathrm{t} / \mathrm{ha}$ as recommended. The treatments were allotted according to the recommended phosphorus and potassium for maize (60:40 $\mathrm{kg} \mathrm{P}_{2} \mathrm{O}_{5}: \mathrm{K}_{2} \mathrm{O} / \mathrm{ha}$. Phosphorus and potassium were applied at the rate of $60 \mathrm{~kg} / \mathrm{ha}$ and $40 \mathrm{~kg} / \mathrm{ha}$ respectfully. Half of the Nitrogen and full phosphorus and potassium were applied at the basal dose. Other crop management practices were carried out as per recommendation of National Maize Research Program (NMRP) Rampur, Chitwan, Nepal.

\section{Data collection and statistical analysis}

Grain yield of maize was estimated using formula adopted by Carangal et al. (1971) and Shrestha et al. (2018b) by adjusting the grain moisture at $15 \%$ and converted to the grain yield $\mathrm{kg}$ per hectare. The analysis of variance was performed using RCBD design to derive variance components derived using GenStat statistical package (12 ${ }^{\text {th }}$ edition) (Payne et al., 2009). The mean comparisons among treatment means were estimated by the least significant difference (LSD) test at $5 \%$ levels of significance (Gomez and Gomez, 1984; Baral et al., 2016).

Table 1. Weather data of experimental site during maize growing period at Rampur, Chitwan, Nepal in spring seasons of 2017 and 2018.

\begin{tabular}{lcccc}
\hline Month/year & Max. Temp $\left({ }^{\circ} \mathrm{C}\right)$ & Min. Temp $\left({ }^{\circ} \mathrm{C}\right)$ & Rainfall (mm) & Relative humidity $(\%)$ \\
\hline February 2017 & 26.91 & 10.38 & 3.40 & 92.51 \\
March 2017 & 29.58 & 13.45 & 64.50 & 87.08 \\
April 2017 & 33.46 & 18.77 & 77.60 & 88.17 \\
May 2017 & 34.77 & 21.29 & 86.30 & 86.81 \\
June 2017 & 35.39 & 24.83 & 179.70 & 86.83 \\
February 2018 & 26.40 & 12.64 & 0.00 & 70.60 \\
March 2018 & 32.62 & 17.99 & 26.00 & 68.07 \\
April 2018 & 34.48 & 22.27 & 35.10 & 75.63 \\
May 2018 & 34.32 & 24.98 & 137.70 & 82.85 \\
June 2018 & 35.16 & 26.55 & 212.20 & \\
\hline
\end{tabular}

(Source: NMRP, 2017; NMRP, 2018). 


\section{RESULTS AND DISCUSSION}

Different yield attributing parameters like grain yield ( $t / h a$ ), numbers of cob/ha and thousand grain weights (g) of maize were estimated for each varieties in both years. The results are presented in Tables 2, 3 and Figure 1.

Yield and yield attributes of maize in 2017

\section{Grain yield (t/ha)}

Hybrid maize is a heavy feeder and more responsive to nutrients (Sarkar et al., 2000). Muza et al. (2004) and Shrestha et al. (2018a) found that the commercial maize hybrids require high nitrogen levels and fertile soils and hybrids are more responsive to nitrogen fertilizer. In the year 2017, both the hybrids RML86/ RML96 and RML95/RML96 produced the highest yield of maize with the use of $150 \mathrm{~kg} \mathrm{~N} / \mathrm{ha}$. The yield of hybrid RML86/RML96 maize was highest (10.5 t/ha) with the application of $150 \mathrm{~kg} \mathrm{~N} /$ ha and that was lowest ( $8.81 \mathrm{t} / \mathrm{ha}$ ) with the use of nitrogen 240 $\mathrm{kg} \mathrm{N} / \mathrm{ha}$. At the same time, RML95/RML96 produced the highest yield of $10.5 \mathrm{t} / \mathrm{ha}$ with application of $150 \mathrm{~kg} \mathrm{~N} / \mathrm{ha}$ and the least yield of $9.18 \mathrm{t} / \mathrm{ha}$ with application of $240 \mathrm{~kg} \mathrm{~N} / \mathrm{ha}$.

\section{Number of cobs/ha}

The highest number of cobs per hectare of maize found in hybrid RML86/RML96 was 69347 cobs/ha with application of $150 \mathrm{~kg}$ $\mathrm{N} / \mathrm{ha}$ and number of cobs/ha for RML95/RML96 was 73722 cobs/ha. These findings are in agreement with those of Bakht et al. (2007), Abbas et al. (2005) and Khan et al. (2014) who reported that numbers of cobs/plant of maize increased with increased in nitrogen rates as compared to control and other treatments.

\section{Thousand grain weights ( $g$ )}

In case of thousand grain weight of maize, the maximum thousand grain weight for RML86/RML96 was 360 gram with application of $150 \mathrm{~kg} \mathrm{~N} /$ ha and that for RML95/RML96 was 355 gram with the use of $150 \mathrm{~kg} \mathrm{~N} / \mathrm{ha}$. The heaviest grains of maize may be due to the utilization of nitrogen which resulted in bold and robust (healthy) seed size at $150 \mathrm{~kg} \mathrm{~N} / \mathrm{ha}$. Amoruwa et al. (1987) reported that thousand grains weight increased with increasing nitrogen rate. Different yield attributing parameters like grain yield ( $t / h a)$, numbers of cobs/ha and thousand grain weights ( $g$ ) were calculated for each varieties in spring season of 2018 spring.

Yield and yield attributes of maize in 2018

\section{Grain yield ( $\mathrm{t} / \mathrm{ha}$ )}

In the year 2018, both maize hybrids RML86/RML96 and RML95/RML96 produced the highest yield with application of $150 \mathrm{~kg} \mathrm{~N} / \mathrm{ha}$. The yield of hybrid RML86/RML96 was highest i.e. $7.49 \mathrm{t} / \mathrm{ha}$ with the use of $150 \mathrm{kgN} / \mathrm{ha}$ and that was the lowest i.e. $15.0 \mathrm{t} / \mathrm{ha}$ with application of nitrogen $120 \mathrm{~kg} \mathrm{~N} / \mathrm{ha}$. At the same time, RML95/RML96 gave the highest yield of $7.68 \mathrm{t} / \mathrm{ha}$ of maize with application of $150 \mathrm{~kg} \mathrm{~N} / \mathrm{ha}$ and the lowest i.e. $6.22 \mathrm{t} / \mathrm{ha}$ with use of $210 \mathrm{~kg} \mathrm{~N} / \mathrm{ha}$. Application of nitrogen provided better nutrition to maize which resulted in higher grain yield. Increase in grain yield of maize with the application of nitrogen may be attributed to better growth of plant. The improvement in growth resulted in significant increase in yield attributes like number of cobs per plant, grains per cob, cob length and cob girth and test weight of $Z$. mays which ultimately contributed to higher grain yield of $Z$. mays with the application of nitrogen. The beneficial effect of nitrogen on grain yield of maize has also been reported by Sahoo and Mahapatra (2004) and Kumar (2008).

Table 2. Yield and yield components of hybrid maize under different rates of nitrogen fertilizer at Rampur, Chitwan, Nepal in spring season of 2017.

\begin{tabular}{|c|c|c|c|c|c|c|c|c|c|}
\hline \multirow{2}{*}{$\begin{array}{l}\text { Nitrogen levels } \\
\text { (kg N/ha) }\end{array}$} & \multicolumn{3}{|c|}{ Grain yield (t/ha) } & \multicolumn{3}{|c|}{ Number of cobs/ha } & \multicolumn{3}{|c|}{ Thousand grain weight (g) } \\
\hline & $\begin{array}{l}\text { RML86/ } \\
\text { RML96 }\end{array}$ & $\begin{array}{l}\text { RML95/ } \\
\text { RML96 }\end{array}$ & Mean & $\begin{array}{l}\text { RML86/ } \\
\text { RML96 }\end{array}$ & $\begin{array}{l}\text { RML95/ } \\
\text { RML96 }\end{array}$ & mean & $\begin{array}{l}\text { RML86/ } \\
\text { RML96 }\end{array}$ & $\begin{array}{l}\text { RML95/ } \\
\text { RML96 }\end{array}$ & mean \\
\hline 120 & 9.96 & 10.07 & 10.2 & 63542 & 70486 & 67014 & 331 & 351 & 341 \\
\hline 150 & 10.5 & 10.5 & 10.5 & 69347 & 73722 & 71535 & 360 & 355 & 358 \\
\hline 180 & 9.53 & 10 & 9.76 & 68056 & 70139 & 69097 & 347 & 335 & 341 \\
\hline 210 & 9.94 & 9.41 & 9.67 & 65625 & 65069 & 65347 & 337 & 340 & 338 \\
\hline 240 & 8.81 & 9.18 & 8.99 & 57708 & 63889 & 60799 & 346 & 331 & 338 \\
\hline Grand mean & 9.75 & 9.83 & 9.79 & 64856 & 68661 & 66758 & & & 342 \\
\hline F-test & & * & & & NS & & & NS & \\
\hline CV\% & & 7.1 & & & 9.2 & & & 6.7 & \\
\hline $\begin{array}{l}\text { LSD (0.05) } \\
\text { Nitrogen }\end{array}$ & & 0.841 & & & 7425.2 & & & 27.77 & \\
\hline $\begin{array}{l}\text { LSD }(0.05) \\
\text { Nitrogen } \times \text { Variety }\end{array}$ & & 1.190 & & & 10500 & & & 39.27 & \\
\hline
\end{tabular}

NS $=$ non-significant at $5 \%$ level of significance, ${ }^{*}=$ Significant at $5 \%$ level of significance. 
Table 3. Yield and yield components of hybrid maize under different rates of nitrogen fertilizer at Rampur, Chitwan, Nepal in spring season of 2018.

\begin{tabular}{|c|c|c|c|c|c|c|c|c|c|}
\hline \multirow[b]{2}{*}{$\begin{array}{l}\text { Nitrogen Levels } \\
\text { (kg N/ha) }\end{array}$} & \multicolumn{3}{|c|}{ Grain yield (t/ha) } & \multicolumn{3}{|c|}{ Number of cobs/ha } & \multicolumn{3}{|c|}{ Thousand grain weight (g) } \\
\hline & $\begin{array}{l}\text { RML86/ } \\
\text { RML96 }\end{array}$ & $\begin{array}{l}\text { RML95/ } \\
\text { RML96 }\end{array}$ & Mean & $\begin{array}{l}\text { RML86/ } \\
\text { RML96 }\end{array}$ & $\begin{array}{l}\text { RML95/ } \\
\text { RML96 }\end{array}$ & Mean & $\begin{array}{l}\text { RML86/ } \\
\text { RML96 }\end{array}$ & $\begin{array}{l}\text { RML95/ } \\
\text { RML96 }\end{array}$ & Mean \\
\hline 120 & 5.01 & 7.09 & 6.05 & 84722 & 91111 & 87917 & 349.3 & 364 & 356.7 \\
\hline 150 & 7.49 & 7.68 & 7.58 & 90000 & 94722 & 92361 & 403.3 & 432 & 417.7 \\
\hline 180 & 7.07 & 6.46 & 6.76 & 81389 & 88333 & 84861 & 366.7 & 402 & 384.3 \\
\hline 210 & 6.99 & 6.22 & 6.6 & 88056 & 88889 & 88472 & 350.7 & 313.3 & 332 \\
\hline 240 & 7.37 & 7.46 & 7.42 & 83056 & 89444 & 86250 & 358 & 389.3 & 373.7 \\
\hline Grand mean & 6.79 & 6.98 & 6.88 & 85444 & 90500 & 87972 & 365.6 & 380.1 & 372.9 \\
\hline F test (Nitrogen $\times$ Variety) & & $* *$ & & & NS & & & NS & \\
\hline CV\% & & 8.8 & & & 6.3 & & & 9.8 & \\
\hline LSD (0.05) Nitrogen & & 0.845 & & & 6686.6 & & & 44.5 & \\
\hline $\begin{array}{l}\text { LSD }(0.05) \\
\text { Nitrogen } \times \text { Variety }\end{array}$ & & 1.195 & & & 9456.2 & & & 62.94 & \\
\hline
\end{tabular}

NS= non-significant at $5 \%$ level of significance, ${ }^{* *}=$ significant at $1 \%$ level of significance.

Number of cobs/ha

Various nitrogen levels affected the number of cobs/ha. The highest number of cobs i.e. 94722 and 90000 cobs/ha of maize were produced by hybrids RML95/RML96 and RML86 /RML96, respectively with application of $150 \mathrm{~kg} \mathrm{~N} / \mathrm{ha}$

\section{Thousand grain weight (g)}

The maximum thousand grain weight of maize obtained from RML86/RML96 was $403.3 \mathrm{~g}$ with the use of $150 \mathrm{~kg} \mathrm{~N} / \mathrm{ha}$ and that trait from RML95/RML96 was $432 \mathrm{~g}$ with the application of $150 \mathrm{~kg} \mathrm{~N} / \mathrm{ha}$. Such positive role of nitrogen in enhancing the test weight of maize is also recorded by Arif et al. (2010) and Salam et al. (2010). The pooled analysis (2017 and 2018) showed that highest grain yields of 9.0 and $9.1 \mathrm{t} /$ ha were produced by hybrid RML86/RML96 and RML95/RML96, respectively with use of $150 \mathrm{~kg} \mathrm{~N} /$ ha (Figure 1).

The results of this experiment indicated the positive response of various yield attributes of maize to higher nitrogen fertilization that was accordance findings of several researchers (Chillar and Kumar, 2006; Bindhani et al., 2007; Gosavi and Bhagat, 2009; Prodhan et al., 2007) who found the higher green cob yield with application of higher nitrogen. They noticed nitrogen had its profound influence on vegetative and reproductive growth of the crop. Yield attributes of maize increased with increased rates of $\mathrm{N}$ might be due to the fact that application of nitrogen to the maize plants maintained greenness of leaves for longer period which in turn helped in greater dry matter accumulation and this might have contributed much as a major source for the development of sink and thereby improved the yield attributes (Asaduzzaman et al., 2014)

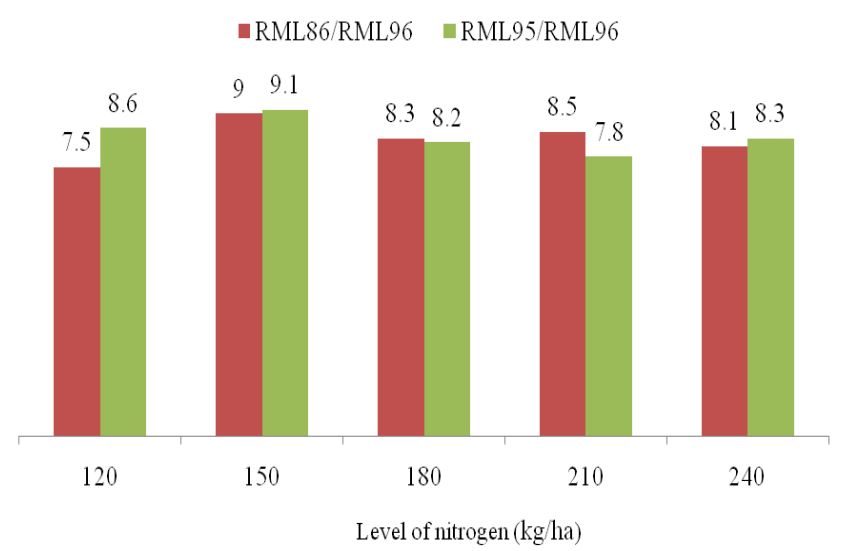

Figure 1. Effects of different levels of nitrogen on grain yield of different maize hybrids at Rampur, Chitwan, Nepal in spring seasons of 2017 and 2018.

\section{Conclusion}

Nitrogen fertilizer application had profound effects on grain yield and yield attributing traits of maize hybrids. The application of nitrogen fertilizer at the rate of $150 \mathrm{~kg} / \mathrm{ha}$ increased the grain yield and yield attributing traits namely number of cobs/ha and thousand grain weight in both hybrids RML86/RML96 and RML95/RML96 in 2017 and 2018. Therefore, the use of this level of nitrogen is beneficial to get the higher maize production.

\section{ACKNOWLEDGEMENTS}

The authors were thankful to National Maize Research Program (NMRP), Rampur, Chitwan, Nepal for providing research field, planting materials, financial and technical supports for these experiments. 


\section{Conflict of interest}

All the authors would like to declare that there is no conflict of interest among them that could possibly arise in future.

Open Access: This is an open access article published under the terms and conditions of Creative Commons AttributionNonCommercial 4.0 International License which permits noncommercial use, distribution, and reproduction in any medium, provided the original author(s) if the sources are credited.

\section{REFERENCES}

Abbas, G., Hussain, A., Ahmad, A. and Wajid, S.A. (2005). Effect of irrigation schedules and nitrogen rates on yield and yield components of maize. Journal of Agriculture and Social Sciences, 1: 335-338.

Adhikari, P., Baral, B.R. and Shrestha, J. (2016). Maize response to time of nitrogen application and planting seasons. Journal of Maize Research and Development, 2(1): 83-93.

Adhikary, B.H. and Adhikary, R. (2013). Enhancing effect of nitrogen on grain production of hybrid maize in Chitwan valley. Agronomy Journal of Nepal, 3 : 33-41, http://dx.doi.org/10.3126/ajn.v3i0.8984

Amoruwa, G.M., Ogunela, V.B. and Ologunda, O.O. (1987). Agronomic performance and nutrient concentration of maize as influence by nitrogen and plant density. Journal of Agronomy and Crop Science, 159: 226-231, http://dx.doi.org/10.1111/j.1439-037X.1987.tb00093.x

Arif, M., Jan, M.T., Khan, N.U., Akbar, H., Khan, S.A., Khan, M.J, Khan, A., Munir, I., Saeed, M. and Iqbal, A. (2010). Impact of plant populations and nitrogen levels on maize. Pakistan Journal of Botany, 42(6): 3907-3913.

Asaduzzaman, Md., Biswas, M., Nazrul Islam, Md. Rahman, Md. M., Begum, R, Sarkar, Md. A.R. and Asaduzzaman, Md. (2014). Variety and N-fertilizer rate influence the growth, yield and yield parameters of baby corn (Zea mays L.). Journal of Agricultural Science, 6(3): 118-131.

Abubakar, A.W., Manga, A.A., Kamara, A.Y. and Tofa, A.I. (2019). Physiological evaluations of maize hybrids under low nitrogen. Advances in Agriculture, 1-6, https://doi.org/10.1155/2019/2624707

Baral, B.R., Adhikari, P. and Shrestha, J. (2016). Productivity and Economics of Hybrid Maize (Zea mays L.) in the Inner Terai Region of Nepal. Journal of AgriSearch, 3(1): 13-16.

Bindhani, A., Barik, K.C., Garnayak, L.M. and Mahapatra, P.K. (2007). Nitrogen management in baby corn (Zea mays L.). Indian Journal of Agronomy, 52: 135138.

Brady, N.C. and Weil, R.R. (1990). The nature and properties of soils. (10 ${ }^{\text {th }}$ ed.) New York: Macmillan.

Carangal, V.R., Ali, S.M., Koble, A.F. and Rinke, E.H. (1971). Comparison of S1 with testcross evaluation for recurrent selection in maize. Crop Science, 11: 658661.

Chillar, R.K. and Kumar, A. (2006). Growth and yield behaviour of sweet corn (Zea mays L. saccharata) under varying plant population and nitrogen level. In Extended Summaries of Golden Jubilee National Symposium on conservation Agriculture and Environment (pp. 277-278). Held during 26-28 October, 2006, Banaras Hindu University, Varanasi, India.

Gomez, K.A. and Gomez, A.A. (1984). Statistical Procedure for Agricultural Research ( $2^{\text {nd }}$ edn.). Int. Rice Res. Inst. and Willey, New York pp. 28-192.

Gosavi, S.P. and Bhagat, S. B. (2009). Effect of nitrogen levels and spacing on yield attributes, yield and quality parameters of baby corn (Zea mays L.). Annals Agricultural Research, 30: 125-128.
Jat, M.L., Satyanarayana, T., Manundar, K., Parihar, C.M., Jat, S.L., Tetarwal, J.P., Jat, R.K. and Saharawat, Y.S. (2013). Indian Journal of Fertilizer, 9(4): 80-94.

Govind, K.C., Karki, T., Shrestha, J. and Achhami, B.B. (2015). Status and prospects of maize research in Nepal. Journal of Maize Research and Development, 1(1): 1-9.

Kandel, M., Ghimire, S.K., Ojha, B.R. and Shrestha, J. (2017). Analysis of genetic diversity among the maize inbred lines (Zea mays L.) under heat stress condition. Journal of Maize Research and Development, 3(1): 86-97, http://dx.doi.org/10.3126/jmrd.v3i1.18925

Khan, F., Khan, S., Fahad, S., Faisal, S., Hussain, S., Ali, S. and Ali, A. (2014). Effect of different levels of nitrogen and phosphorus on the phenology and yield of maize varieties. American Journal of Plant Sciences, 5: 2582-2590, http://dx.doi.org/10.4236/ajps.2014.517272

Kumar, A. (2008). Productivity, economics and nitrogen-use efficiency of specialty corn (Zea mays L.) as influenced by planting density and nitrogen fertilization. Indian Journal of Agronomy, 53(4): 306-309.

Marschner, H. (1995). Mineral nutrition of higher plants. $2^{\text {nd }}$ edn. Academic Press, New York, pp. 889.

MOALD. (2018). Statistical information on Nepalese agriculture 2070/71. Agri-business Promotion and Statistics Division. Ministry of Agriculture Development, Kathmandu, Nepal.

Muza, L., Waddington, S.R. and Banziger, M. (2004). Preliminary results on the response of nitrogen use efficient $\mathrm{OPV}$ and hybrid maize to $\mathrm{N}$ fertilizer on smallholder fields in Zimbawe. In: Integrated approaches to higher maize productivity in the new millennium: Proceedings of the seventh eastern and southern Africa regional maize conference, Nairobi, Kenya, CIMMYT African Livelihoods Program, pp. 245.

NMRP. (2017). Annual Report 2073/74 (2016/17). National Maize Research Program, NARC, Rampur, Chitwan, Nepal.

NMRP. (2018). Annual Report 2074/75 (2017/18). National Maize Research Program, NARC, Rampur, Chitwan, Nepal.

Nxumalo, E.M., Pali-Shikhulu, J. and Dlamini, S.M. (1993). Assessment of nitrogen fertilizer use in commercial hybrids. SADC-Land and Water Research Programme, Proceedings of the Fourth Annual Scientific Conference, Windhoek, Namibia, pp: 322- 329.

Onasanya, R.O., Aiyelari, O.P., Onasanya, A., Oikeh, S., Nwilene, F.E. and Oyelakin, O.O. (2009). Growth and yield response of maize (Zea mays L.) to different rates of nitrogen and phosphorus fertilizers in Southern Nigeria. World Journal of Agricultural Sciences, 5(4): 400-407.

Payne, R., Murray, D.A, Harding, S.A., Baird, D.B and Soutar, D.M. (2009). Genstat for Windows $\left(12^{\text {th }}\right.$ Edition) Introduction, VSN International, Hemel Hempstead, UK, 2009.

Prodhan, H.S., Bala, S. and Khoyumthem, P. (2007). Response to rate of nitrogen and effect of plant density on yield of baby corn. Journal of Interacademicia, 11: 265-269.

Sahoo, S.C. and P.K. Mahapatra. (2004). Response of sweet corn (Zea mays) to nitrogen levels and plant population. Indian Journal of Agricultural Sciences, 74 (6): 337-338

Salam, M.A., Sarder, M.S.A, Ullah, M.J., Kawochar, M.A. and Islam M.K. (2010). Effect of different spacing and levels of nitrogen fertilizer on the yield attributes and yield of hybrid maize. Journal of Experimental Biosciences, 1(2): 57-61.

Sarkar, A.K., Singh, K.P., Singh, B.P. and Singh, R.P. (2000). Long term effects of fertilizers, manures and amendments on crop production and soil fertility. Technical Bulletin of Soil Science and Agricultural Chemistry (BAU) No.2/2000. pp. 31- 45.

Shrestha, J., Chaudhary, A. and Pokhrel, D. (2018a). Application of nitrogen fertilizer in maize: a review. Peruvian Journal of Agronomy, 2 (2): 22-26

Shrestha, J., Yadav, D.N., Amgain, L.P. and Sharma, J.P. (2018b). Effects of nitrogen and plant density on maize (Zea mays L.) phenology and grain yield. Current Agriculture Research Journal, 6(2): 175-182. 